\title{
The Effect of Learning Strategies on Mathematics Learning Outcomes at Bekasi State Vocational High School 7
}

\author{
Arum Setyowati ${ }^{1}$, Zulfiati Syahrial ${ }^{2}$, and Diana Nomida Musnir ${ }^{2}$ \\ ${ }^{1}$ Department of Educational Technology, University Postgraduate Program Negeri Jakarta, \\ Indonesia \\ ${ }^{2}$ Educational Technology, Universitas Negeri Jakarta, Indonesia
}

Corresponding Author:

Arum Setyowati

asetyowati@unj.ac.id

Received: 11 January 2019

Accepted: 14 February 2019

Published: 25 March 2019

Publishing services provided by Knowledge E

(c) Arum Setyowati et al. This article is distributed under the terms of the Creative Commons Attribution License, which permits unrestricted use and redistribution provided that the original author and source are credited.

Selection and Peer-review under the responsibility of the 3rd ICTVET 2018 Conference Committee.

\section{Abstract}

This study aims to determine whether there are differences in mathematics learning outcomes between students who are taught using inquiry learning strategies and expository learning strategies at Bekasi State Vocational High School 7. This is an experimental research with research design using Pretest-Posttest Control Group Design. The population in this study were all students in the Audio Video Engineering Department. Sampling was done through simple random sampling technique, and the students of class XI TAV 1 obtained were the experimental class given treatment with inquiry learning strategies and students of class XI TAV 2 were the control classes treated with expository learning strategies. The instrument used in this study was posttest to measure mathematics learning outcomes. Data analysis consisted of normality test using Lilliefors test and homogeneity test using Fisher's test. The results of the calculation of the normality test in the class using inquiry learning strategies amounted to 1.154 and the class using the expository learning strategy of 1.116 with $\mathrm{L}_{\text {table }} 1.161$, then the data was normally distributed. The homogeneity test obtained the results of $F_{\text {count }} 1.75$ less than $F_{\text {table }} 1.87$, the data were homogeneously distributed. Statistical hypothesis calculations using $t$-test with $t_{\text {count }} 2.12$ is greater than $t_{\text {table }} 2.00$, so it can be concluded that there are effects of learning outcomes between students who use inquiry learning strategies and students who use expository learning strategies Keywords: learning strategy, learning outcomes, audio video engineering

\section{Introduction}

Vocational High School (SMK) is a secondary education level that prepares students by providing them with knowledge and skills to work in accordance with their fields of expertise. SMK Negeri 7 Bekasi has four majors namely Audio Video Engineering, Industrial Automation Engineering, Accounting and Light Vehicle Engineering. The learning process in Curriculum 2013 for junior and senior high school or equivalent is carried out using a scientific approach. The 2013 Curriculum learning process must 
touch three domains, namely attitudes, knowledge and skills. The learning process is emphasized in the realm of attitude. In the scientific approach based learning process, the realm of attitude must be able to be used to transform substance so that students know and understand the cause of a material or are assumed by the question "why". The question why makes students able to be kind in an integrative and comprehensive understanding of a particular material. The domain of knowledge is used to transform the substance so that students know and understand a certain content is assumed with the question "what". The end result is an increase and balance between the ability to be a good human being (soft skills) and a human who has the skills and knowledge to live properly (hard skills) from students which includes aspects of attitudes, skills and knowledge competencies [1].

The low mathematics learning outcomes according to the mathematics teacher of technology and industry Vocational High School (SMK) are caused by the lack of attention and seriousness of the students following the teaching and learning process. Less attention from students in following the mathematics learning process is generally caused by a lack of understanding of students about the benefits of mathematics in the world of work. Another factor is the learning strategy developed by mathematics teachers has not made students interested in learning mathematics.

The results of observations conducted by researchers in class XI TAV1 and XI TAV 2 that in the process of learning mathematics the teacher applies the expository learning strategy. In expository learning strategies the learning process is centered on the teacher through lectures, question and answer, training and assignment. The application of expository learning strategies has not been able to improve students' learning motivation. This can be seen from some students who have not clearly understood the material delivered by the teacher, because when the teacher delivers the material there are students who lack concentration and chat with other students. But there are some other students who can understand the material delivered directly by the teacher. When the teacher gives students the opportunity to ask questions, the students are only silent, students feel embarrassed, lack confidence, and are afraid even though some are not understood. Less understanding of students about the material delivered will affect the learning outcomes of students. Learning outcomes are obtained after examinations such as daily tests, midterms and final semester examinations. Achieving good learning outcomes if students can achieve the KKM score (Minimum Completion Criteria). KKM for mathematics subjects at SMK Negeri 7 Bekasi in the 2018/2019 school year is 75 . So from the KKM criteria, students are declared successful if they get a minimum score of 75 . If they get a score below 75 , students must repeat or follow remedial. 
To achieve KKM, teachers make various efforts to improve student learning outcomes such as giving assignments at home, group assignments and discussions. One effort is used to improve student learning outcomes by applying learning strategies. Learning strategies are expected to change the atmosphere of teaching and learning activities to be more interesting and make students more enthusiastic and active in learning.

Based on the description that has been stated, it appears that the role of learning strategies in mathematics learning activities is very important. For this reason, it is deemed necessary to conduct a study on the effect of learning strategies on the learning outcomes of mathematics at SMK Negeri 7 Bekasi.

Learning strategies in this study are general guidelines for the activities of teachers and students in realizing effective learning events to achieve certain goals, which are formed by a blend of learning activities, methods, and media. In this study two learning strategies were tested, namely expository learning strategies and inquiry learning strategies.

According to Dick and Carey learning strategies explain the common components of a set of material and learning procedures that will be used with other materials to express certain learning outcomes on the part of students [2]. Branch explained that the learning strategy is an organization and details or specifications of activities in learning [3]. Spector et. al explained that a learning strategy includes those involving student activities with a model, this often refers to the mental theory of the model [4].

According to Moore, inquiry learning strategies are basically problem solving techniques [5]. The output of learners in inquiry learning according to Arends is gaining knowledge about the focus of inquiry, developing thinking knowledge and reasoning skills, developing metacognitive skills, developing positive attitudes towards inquiry and appreciation of knowledge [6]. The model of inquiry exercise has been developed by Richard Suchman to teach students about the process of researching and explaining foreign phenomena. This Suchman model involves students in small versions of the types of procedures used by scholars to process knowledge and produce principles. Based on the conception of the scientific method, this model tries to teach students some skills and languages of scientific research. The syntax of inquiry learning strategies are: (1) dealing with problems, (2) collecting data (verification), (3) collecting data (experimentation), (4) processing, formulating an explanation, (5) analyzing the research process [7].

According to Jonassen, learning involving teachers or tutors or learning systems in making decisions for students, shows which resources will be used and what activities should be carried out [8]. Direct learning strategies (direct instruction) according to 
Eggen and Kauchak are learning models designed to teach the knowledge and skills needed for further learning [9]. This strategy is very effective in teaching students with low achievement, so there needs to be a variety of strategies in learning, so that learning objectives can be achieved effectively. The syntax of expository learning strategies are: (1) Preliminary activities consisting of three stages of activity, namely providing motivation and attracting students' attention, explaining learning objectives and subject matter to be studied by students, and giving pre-tests, (2) Core activities consisting for four stages of activity, namely explaining the contents of the lesson, giving examples relating to the subject matter, giving questions to students, and giving problem training to students, (3) Closing activities consisting of two stages of activities, namely conducting tests and giving homework to students.

The research hypothesis is: "It is suspected that there are differences in mathematics learning outcomes between students who learn with inquiry learning strategies and students who learn with expository learning strategies"

\section{Methods}

This research was conducted at Bekasi State Vocational High School 7 in the odd semester of the 2018-2019 academic year. The method used is the experimental method.

According to Emzir (2008: 64) the experimental method is a research method that can correctly test hypotheses regarding causal relationships. The researcher used the experimental method to find out whether there was influence of the students being taught by using inquiry learning strategies and expository learning strategies on the students' mathematics learning outcomes.

The design of this study is to use the Pretest-Posttest Control Group Design. The implementation of this design, determined two groups selected randomly, namely the experimental group and the control group. Then the two groups were given a pretest to find out the initial condition before being given treatment, while the posttest was given after being given treatment to determine the differences in the learning outcomes of the experimental group and the control group. The dependent variable in this study is the results of student mathematics learning. Independent treatment variables are learning strategies, which are divided into two groups, namely inquiry learning strategies as experimental groups and expository learning strategies as a control group. 
The instrument used in this study was posttest to measure mathematics learning outcomes. Data analysis consisted of normality test using Lilliefors test and homogeneity test using Fisher's test. To test the statistical hypothesis is done using the $t$-test.

\section{Results and Discussion}

\subsection{Normality test}

Normality test is done to assess the distribution of data in a group derived from a population with normal distribution or not. In this study to calculate the normality test using the Lilliefors test. The testing criteria are as follows:

1. Accept $\mathrm{H}_{0}$ if $\mathrm{L}_{\text {count }}<\mathrm{L}_{\text {table }}$

2. Reject $\mathrm{H}_{0}$ if $\mathrm{L}_{\text {count }}>\mathrm{L}_{\text {table }}$

Calculation of normality test with Lilliefors test can be shown with the following table 1:

TABLE 1: Normality Test Result.

\begin{tabular}{|l|c|c|c|c|c|}
\hline Group & $\begin{array}{c}\text { Number of } \\
\text { Sample }\end{array}$ & $\begin{array}{c}\text { Levels } \\
\text { Significant }\end{array}$ & Lcount & Ltable & Description \\
\hline Experiment & 29 & 0.05 & 0.154 & 1.161 & Normal \\
\hline Control & 29 & 0.05 & 0.116 & 1.161 & Normal \\
\hline
\end{tabular}

Based on the table, in the experimental group using a significant level of 0.05 with a sample of 29 people obtained $\mathrm{L}_{\text {table }}$ of 1.161 . After calculation, the Lilliefors test was obtained by $\mathrm{L}_{\text {count }}$ of 0.154 . Because $\mathrm{L}_{\text {count }}$ is less than $\mathrm{L}_{\text {table }}(0.154<1.161)$, it can be concluded that in the experimental group the data came from the normal distribution population. Whereas in the control group, with a significant level of 0.05 and a sample of 29 people obtained $\mathrm{L}_{\text {table }}$ of 1.161 . After calculation, $\mathrm{L}_{\text {count }}$ is 0.116 . Because $\mathrm{L}_{\text {count }}$ is less than $\mathrm{L}_{\text {table }}(0.116<1.161)$, it can be concluded that in the data control group comes from the normal distribution population.

\subsection{Homogeneity test}

In this study, homogeneity tests were carried out using the Fisher test. The testing criteria is $\mathrm{F}_{\text {count }}$ less than $\mathrm{F}_{\text {table }}$. From the calculation results, the variance values in the experimental group were 75.95 and in the control group 132.97. So that obtained $F_{\text {count }}$ of 1.75 with a significant level of 0.05 for $\mathrm{dk} 1=28$ and $\mathrm{dk} 2=28$ then obtained $\mathrm{F}_{\text {table }}$ of 
1.87. Based on the calculation results, $F_{\text {count }}$ is less than $F_{\text {table }}(1.75<1.87)$ so it can be concluded that the variance of the two populations is homogeneous.

TABLE 2: Homogeneity Test Results.

Variance
Experiment
75.95
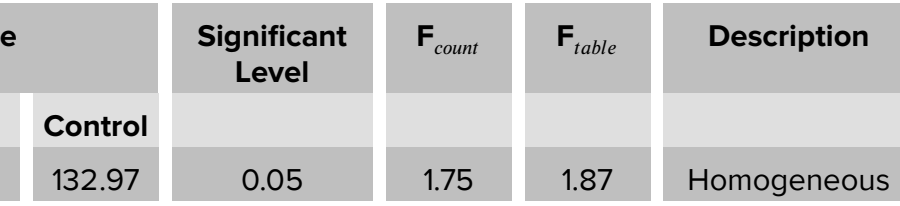

\subsection{Hypothesis testing}

After conducting the prerequisite test and it is known that the two groups are normally distributed and homogeneous, then the next testing phase is testing the hypothesis with the $t$-test. The hypotheses obtained are: "Inquiry Learning Strategies and Expository Learning Strategies can Influence Mathematics Learning Outcomes". The criteria for testing the hypothesis in this study are:

1. $\mathrm{H}_{0}$ is rejected if $\mathrm{t}_{\text {count }}>\mathrm{t}_{\text {table }}$

2. $\mathrm{H}_{0}$ is accepted if $\mathrm{t}_{\text {count }}<\mathrm{t}_{\text {table }}$

Based on the results of testing the average value of posttest mathematics subjects by using the $t$-test, the value of $\mathrm{t}_{\text {count }}=2.12$ with $\mathrm{dk}=56$ and a significant level of 0.05 is obtained $t_{\text {table }}=2.00$. The calculation results show that the value of $t_{\text {count }}>t_{\text {table }}(2.12$ $>2.00$ ) then $\mathrm{H}_{0}$ is rejected and $\mathrm{H}_{1}$ is accepted, so it can be concluded that there is an effect of learning outcomes between students who use inquiry learning strategies and students who use expository learning strategies.

In class XI TAV1, the average score of the pretest was 24.02 with the lowest score of 13 and the highest of 36 obtained from 29 students. After students were treated using the inquiry learning strategy during teaching and learning activities, the average posttest score was 76.62 with the lowest score of 56 and the highest score of 86 with 29 students.

In class XI TAV2, the average value of the pretest was 28.52 with the lowest score of 16 and the highest score of 43 with the number of students 29 people. In class XI TAV2, treatment was given using the expository learning strategy. After being given treatment, the average value of the students became 70.72 with the lowest score of 53 and the highest score of 90 with the number of students 29 people. 
The results of these calculations indicate that inquiry learning strategies and expository learning strategies can improve mathematics learning outcomes and have significant differences in learning outcomes. The inquiry learning strategy is superior to the expository learning strategy. This is indicated by the results of the average grade of inquiry learning strategies greater than the results of the class average expository learning strategies.

The inquiry learning strategy is superior because it emphasizes more on group learning where students must be responsible for their own success or group, encourage students to help each other in understanding the material taught because the success of each student is also determined by other students in the same group.

\section{Conclusion}

Based on the results of testing the hypothesis in the discussion that has been explained, it can be concluded that the results of research conducted at Bekasi State Vocational High School in class XI majoring in TAV 1 and TAV 2 show there are differences in student learning outcomes by applying inquiry learning strategies and expository learning strategies.

\section{Acknowledgement}

The authors would like to thank Dr. Zulfiati Syahrial and Dr. Diana Nomida Musnir for giving them the guidance, patience, and being the best inspiring supervisors.

\section{References}

[1] Muhammad Fathurrohman. (2015). 2013 Curriculum Learning Paradigm. Yogyakarta: Kalimedia. p. 108.

[2] Walter Dick, Lou Carey. (2006). The Systematic Design of Instruction 6th Edition. Boston: Allyn and Bacon, Pearson. p. 171.

[3] Robert Maribe Branch. (2009). Instructional Design: The ADDIE Approach. New York: Springer. p. 85.

[4] J. Michael Spector et al. (2014). Handbook of Research on Educational Communications and Technology. New York: Springer. p. 960.

[5] Kenneth D. Moore. (2005). Effective Instructional Strategies From Theory to Practice. California: Sage Publications, Inc. p. 227. 
[6] Richard I. Arends. (2015). Learning To Teach. New York: McGraw Hill. p. 313.

[7] Bruce Joyce et al. (2009). Models of Teaching. New York: Pearson Education. pp. 375-376.

[8] David H. Jonassen. (2013). Learning, Problem Solving, and Mindtools. New York: Routledge. p. 299.

[9] Paul Eggen and Don Kauchak. (2007) Educational Psychology. Ohio: Merril Pearson. p. 423.

[10] Emzir,. (2008). Quantitative and Qualitative Education Research Methodology. Jakarta: PT Rajagrafindo Persada. 